\title{
Sposoby ukazywania obozów nazistowskich w sztuce zwanej naiwną
}

\begin{abstract}
Grzybowska Katarzyna, Sposoby ukazywania obozów nazistowskich w sztuce zwanej naiwną [Nazi camps as depicted in naive art]. "Przestrzenie Teorii" 23. Poznań 2015, Adam Mickiewicz University Press, pp. 121-135. ISBN 978-83-232-2920-9. ISSN 1644-6763. DOI 10.14746/pt.2015.23.8.
\end{abstract}

The paper presents the realizations of the theme of concentration camps in folk art, i.e. the sculptures made by Władysław Chajec, Zygmunt Skrętowicz, Franciszek Skocz, and Jan Staszak. Chajec and Staszak tried to present the most drastic moments in the history of the Nazi death factories. These sculptors drew inspiration from the popular iconography of the Holocaust, i.e. pictures showing the liberation of the camps. Skocz carved a cycle of figures that represent members of the SS and prisoners who are doing labor and who are being subjected to punishment, whereas Staszak decided to create his works by using wood from the trees growing on the borders of the Auschwitz-Birkenau camp, thus treating these plants as witnesses of suffering. This article presents the aforementioned works against the background of the crisis of representation, which permeates culture after the Holocaust.

W pracy Sztuka po Holokauście Eleonora Jedlińska postawiła pytanie o postawę człowieka - artysty wobec Zagłady Żydów. Badaczka ukazuje tę kwestię jako kluczową dla twórczości powstającej po drugiej wojnie światowej, zagadnienie stale obecne w naszej kulturze, od którego powojenni artyści nie mogą abstrahować. Jedlińska zawęziła przedstawione w książce analizy do dwóch grup twórców. Pierwszą z nich stanowią artyści, dla których Holokaust stał się doświadczeniem bezpośrednim - z uwagi na traumatyczny charakter przeżyć i natrętną obrazowość wspomnień nie potrafili oni oczyścić swoich dzieł z realistyczno-dokumentacyjnych obrazów budowanych za pomocą języka, który po Holokauście okazał się niezdatny do opowiedzenia traumy. Drugą zaś autorzy, którzy poznali Zagładę pośrednio, poprzez opowieści, świadectwa, fotografie - starali się oni obrazować niemożność wyrażenia doświadczenia Holokaustu, swoisty brak i rozdarcie cechujące kulturę po ludobójstwie - doświadczeniu negującym dotychczasowe formy reprezentacji. Tej grupy twórców dotyczyć mają przytaczane przez Jedlińską słowa Rona B. Kisaja, że „sztuka może i powinna podejmować kwestię Shoah”. Wykazując się empatią względem twórców bezpośrednio do-

${ }_{1}^{1}$ Zob. np. E. Jedlińska, Sztuka po Holocauście, Łódź 2001. 
tkniętych Holokaustem, badaczka uznaje jednocześnie ich sztukę za świadectwo niemożności wypowiedzenia Zagłady za pomocą przedwojennej estetyki ${ }^{2}$, zgadzając się przy tym $\mathrm{z}$ cytowaną przez siebie diagnozą Doreet LeVitte-Harten:

Artyści, którzy dawali świadectwa swych przeżyć, czynili z dokumentacji złą sztukę. Nie dlatego, że byli złymi artystami, lecz dlatego, iż stanęli wobec wydarzenia, którego nikt przed nimi nie próbował zobrazować. Zmagali się z nagimi faktami pozbawionymi ikonografii. Nie istniała tradycja przedstawiania wizerunku komór gazowych. Istniało jednak pragnienie uśmierzenia bólu za pomocą piękna ${ }^{3}$.

Jedlińska zdaje się sugerować, że prace analizowanych przez nią artystów, takich jak Francis Bacon, George Segal, Magdalena Abakanowicz, Christian Boltański czy Mirosław Bałka są już realizacjami pewnej, trzeba przyznać, bardzo niejednolitej wewnętrznie, ikonografii sztuki po Holokauście, za której wyróżniki można by uznać choćby negację figuralności, brak dosłowności, operowanie wzniosłością, wykorzystywanie takich materiałów, jak gips, mydło, używane ubrania, oszczędność w obrazowaniu. Język ten ukazuje Jedlińska jako aestetyczny, co uznać trzeba za założenie co najmniej dyskusyjne ${ }^{4}$. W mojej pracy interesuje mnie sztuka pozostająca poza obrębem analiz Jedlińskiej - twórczość osób, które nie zostały bezpośrednio dotknięte przez Holokaust, a jednocześnie nie podążają ścieżką pozytywnie waloryzowaną przez autorkę Sztuki po Holokauście i usiłują oddać doświadczenie Zagłady w sposób obrazowy, za pomocą znanych sobie sposobów reprezentacji - mam tu na myśli rzeźbę ludową. Jej twórcy, poruszając tematykę obozów, sięgali niejednokrotnie do tradycyjnego stylu rzeźb sakralnych, świątków, stosując przy tym konwencjonalny materiał - drewno.

Do dziś sztuka ludowa kojarzona jest przede wszystkim z figurami świętych, specyficzną ornamentyką, szopką i ruchomymi drewnianymi zabawkami pomalowanymi w przykuwający uwagę sposób. Stawianie pytań o reakcję jej twórców na wydarzenia drugiej wojny światowej i związanej z nią Zagłady rzadko przychodzi do głowy badaczom pamięci5, uznającym co prawda Holokaust za centralny kryzys kultury Zachodu,

2 Ta ogólna teza Jedlińskiej brzmi mniej jednoznacznie w częściach, które poświęca przedstawieniu i krótkiej interpretacji prac poszczególnych autorów.

${ }^{3}$ D. LeVitte-Harten, Przekładanie bólu na kolor, katalog wystawy Galerii Zachęta w Warszawie Gdzie jest brat Twój, Abel?, Warszawa 1995, s. 14.

${ }_{4}^{4}$ Pracę Jedlińskiej uważam za znakomitą, jednak przytoczone ciche założenie wydaje mi się co najmniej dyskusyjne.

${ }_{5}^{5}$ Mam tu na myśli przede wszystkim Memory Studies skoncentrowane wokół zagadnień związanych z Zagładą. 
wobec którego środowiska artystyczne zmuszone zostały do redefinicji podstawowych pojęć, mającym jednak zarazem skłonność do ograniczania tego typu wniosków do obszaru sztuki wysokiej, refleksyjnej. Tymczasem badacze kultury ludowej zaobserwowali, iż po drugiej wojnie światowej6 rzeźba ludowa została wzbogacona o tematykę świecką, głównie wizerunki bohaterów narodowych, motywy obyczajowe zaczerpnięte z codziennego życia wsi i ilustracje przeżyć wojennych? ${ }^{7}$ Istnienie sztuki ludowej poświęconej Holokaustowi, czy szerzej obozom hitlerowskim, jest dziś postrzegane jako zaskakujące, co musi dziwić w kontekście jej dawnej nobilitacji - w roku 1967 podczas polskiego tygodnia w Hamburgu polską sztukę ludową reprezentowały dzieła malarskie „Marii Korak i Nikifora oraz figury Zygmunta Skrętowicza"8. O tych ostatnich pisał Ludwik Cwynar, posiłkując się informacjami z tygodnika „Kultur und unserer Zeit”:

Wstrząsające wrażenie zrobiły cykle rzeźb „Oświęcim” i „Bełżec”. Były to na ogół polichromowane płaskorzeźby, często podzielone na dwa plany: górny zajęty przez okrutnych oprawców i dolny - ze sponiewieranymi ich ofiarami (kompozycja pasowa spotykana w pracach prymitywistów $)^{9}$.

Skoro w 1967 roku figury te były rozpoznawalne na tyle, by reprezentować polską sztukę za granicą, musi zaskakiwać ich nieobecność w dzisiejszej świadomości badawczej. Można postawić tezę, iż sztuka ludowa nie wydaje się akademikom predestynowana do poruszania tematu obozów i z tego względu jest pomijana w refleksji dotyczącej twórczości związanej z Zagładą. Co więcej, najbardziej rozpowszechnionym wśród twórców ludowych wizerunkiem Żyda jest tak zwany chałaciarz, Żydek, przyjmujący też postać Żyda z pieniążkiem - stereotypowy wizerunek krytykowany jako stygmatyzujący czy wręcz antysemicki. Analizując twórczość ludową poświęconą tematowi obozów hitlerowskich, warto zwrócić szczególną uwagę na postaci Żydów, spytać o ich obecność, fizjonomię oraz sposoby wyróżnienia spośród pozostałych postaci. Nie należy przy tym zapominać o polityczno-społecznym kontekście powstania analizowanych prac: w latach sześćdziesiątych i siedemdziesiątych to partie komunistyczne proponowały twórcom listę „odpowiednich” tematów, a dotyczyło to zwłaszcza artystów ludowych, których państwo otoczyło

6 S. Krzysztofowicz, O sztuce ludowej $w$ Polsce, Warszawa 1972. Niektórzy widzą początek tego procesu w dwudziestoleciu międzywojennym, jak na przykład Józef Grabowski.

7 Tamże, s. 30, 40-41.

${ }^{8}$ L. Cwynar, Ku ludowości, „Łabuź” 2002, nr 43, za: <http://labuz.art.pl/archiwlabuz/ 043labuz.html> [15.09.2013].

9 Tamże. 
mecenatem poprzez cykliczne zakupy prac gromadzonych $\mathrm{w}$ muzeach etnograficznych. Takie zamawiane prace zakładały przekształcenie tematu w ideologiczny komunikat ${ }^{10}$.

Badacze zajmujący się sztuką związaną z Holokaustem podkreślają, że jego najtragiczniejsze aspekty wymagają znaczącego milczenia, nie są ukazywane w sposób figuratywny i dosłowny, gdyż tego typu przedstawienie rodzi zarazem naiwność i patos, kicz, który nie przystoi tej tematyce ${ }^{11}$. W takim kontekście $\mathrm{z}$ dosłowności obrazowania sztuka ludowa może wydawać się skazana na klęskę. Nawet jeśli to prawda, refleksja nad nią wydaje się stanowić znaczący kontekst w refleksji nad sztuką powstającą po Holokauście.

\section{Władysław Chajec, Krematorjum}

Powstała w 1965 roku drewniana płaskorzeźba zatytułowana Krematorjum [pisownia oryginalna] autorstwa Władysława Chajca przedstawia palenie zwłok. W centralnym punkcie kompozycji znajdują się ceglany piec krematoryjny, opatrzony kominem, z którego unosi się gęsty, czarny dym oraz sterta nagich ciał. Na płaskorzeźbie przedstawiono też dwóch członków Sonderkommando, którzy zajęci są pracą przy paleniu zwłok. Zwraca uwagę fakt, że palone ciała nie zostały pozbawione włosów, co jest sprzeczne zarówno ze standardową praktyką, jak i powszechną wiedzą o niemieckich fabrykach śmierci. Trudno ustalić tożsamość etniczną ofiar, jedynie fakt, że wszystkie one mają włosy w kolorze czarnym, może sugerować żydowskie pochodzenie. Członkowie Sonderkommando zostali natomiast przedstawieni jednoznacznie jako Żydzi, co da się rozpoznać nie tylko po barwie ich włosów, ale przede wszystkim po dość wydatnych, choć nie karykaturalnych nosach. Drewniana płaskorzeźba została pokryta lakierem i farbą pokostową w ciemnych, mrocznych barwach: na brunatnym tle wyraźnie odznaczają się nagie, jasne ciała. Zobrazowana przez Chajca scena jest wyraźnie inspirowana zdjęciami krematorium wykonanymi tuż po wyzwoleniu KL Dachau. Przerażeni na widok śladów zbrodni niemieckiej żołnierze amerykańscy, którzy wyzwolili obóz, wykonali wiele zdjęć mających stanowić jej świadectwo. Powstała między innymi kontrowersyjna seria upozowanych fotografii przedstawiających pracę przy paleniu zwłok. Kształt pieca krematoryjnego, ukazane na płaskorzeźbie narzędzia pracy Sonderkommando oraz układ poszczególnych

10 Zob. J. Studzińska, Socrealizm w malarstwie polskim, Warszawa 2014, s. 296-306.

11 Zob. L. Saltzman, Awangarda $i$ kicz raz jeszcze. O etyce reprezentacji, przeł. K. Bojarska, „Literatura na Świecie” 2004, nr 1-2, s. 204. 
elementów wyraźnie wskazują, że artysta bezpośrednio inspirował się wspomnianą serią fotografii, uzupełniając jedynie kompozycję o widoczny na wielu ujęciach $\mathrm{z}$ obozu stos wychudzonych ludzkich ciał. W płaskorzeźbie nie ma nic ludycznego, jej kompozycja wydaje się świadczyć o chęci udokumentowania przez artystę najstraszliwszych, a przez to najbardziej przemawiających do wyobraźni wydarzeń związanych z wojną. Rzeźba Chajca w drastyczny sposób łamie postulowany przez część filozofów i badaczy kultury zakaz przedstawiania Zagłady. Z dużą dozą prawdopodobieństwa można jednak założyć, że jej autor nigdy nie spotkał się z żadną z wariacji na temat pytania Theodora Adorna o możliwość tworzenia poezji (sztuki) po Oświęcimiu. Jedną z zasadniczych wątpliwości, jakie doprowadziły krytyków i teoretyków sztuki do zanegowania (lub przynajmniej podania w wątpliwość) figuratywnych przedstawień Zagłady było niebezpieczeństwo przesłonięcia wymiaru etycznego przez warstwę estetyczną pracy, estetyzacja Shoah, którą dość powszechnie uważa się za negatywną (wątpliwą) moralnie. Wydaje się jednak, iż sztuka ludowa, paradoksalnie dzięki typowym dla siebie niedociągnięciom natury formalnej i prymatowi ekspresji nad maestrią, unika w tym wypadku takiego niebezpieczeństwa. W rzeźbie tej nie znajdziemy pragnienia uśmierzenia bólu za pomocą piękna ${ }^{12}$, ale raczej rozpaczliwą próbę zrozumienia zdarzeń niewyobrażalnych.

\section{Zygmunt Skrętowicz, cykl Oświęcim}

Zgromadzony w Państwowym Muzeum Etnograficznym w Warszawie cykl pięciu polichromowanych płaskorzeźb Zygmunta Skrętowicza, wykonanych około 1962 roku, przedstawia najbardziej charakterystyczne, a przy tym emblematyczne elementy funkcjonowania obozu, takie jak transport, kremacja zwłok, wieszanie czy gazowanie więźniów. To realizacje scen na stałe wpisanych w kulturową pamięć Zagłady. Wszystkie płaskorzeźby z cyklu zostały wykonane w kształcie tablic mojżeszowych charakterystycznym również dla macew ${ }^{13}$.

Pierwsza z nich, zatytułowana Nowy transport, ma dwudzielną budowę. W górnej części przedstawiono żołnierza mierzącego z karabinu do idącej przed nim kobiety z dzieckiem. Pomiędzy postaciami twórca umie-

12 Które, na trwale wpisane w tradycję ikonograficzną, według Doreet LeVitte-Harten prowadziło artystów - dokumentatorów do tworzenia złej sztuki. D. LeVitte-Harten, Przekładanie bólu na kolor, s. 14, cyt. za: E. Jedlińska, Sztuka po Holocauście, s. 14.

13 Płaskorzeźby mają zbliżone wymiary kolejno 28 x $35 \mathrm{~cm}, 36$ x $21 \mathrm{~cm}, 35$ x $25 \mathrm{~cm}$, 26 x $35 \mathrm{~cm}$ i $35 \times 28 \mathrm{~cm}$. 
ścił barwnego ptaka. W dolnej części rzeźby widać gęsty tłum niosących tobołki postaci cywilnych różnej płci, w tym dzieci. Są one prowadzone przez dwóch mężczyzn w niebieskich, zapewne policyjnych mundurach.

Druga, również dwudzielna kompozycja zatytułowana Krematorium ponownie wyraźnie bazuje na wspomnianym w niniejszym artykule cyklu fotografii komór gazowych zarejestrowanych w Dachau. Tło stanowi w tym przypadku ceglana ściana, przywodząca na myśl materiał, z jakiego zbudowano krematorium. Górna część płaskorzeźby przedstawia trzech mężczyzn, z których tylko jeden ma na sobie obozowy pasiak, zaś dwóch pozostałych nosi uniformy. Transportują oni wychudzone, nagie ciało do pieca krematoryjnego za pomocą charakterystycznych szczypiec znanych ze zdjęć zrobionych w Dachau ${ }^{14}$. Dolny fragment kompozycji przedstawia dwóch więźniów w pasiakach wkładających ciało do komory pieca. Ich układ, a nawet fryzura i nakrycie głowy poszczególnych osób, jak również stosowane przy „pracy” narzędzia dokładnie odwzorowują zdjęcia z budynku krematorium w KL Dachau.

Trzecia część cyklu - Wieszanie - różni się od poprzednich układem przestrzennym w górnej, polichromowanej na biało półokrągłej części płaszczyzny widnieje brązowa wiewiórka umieszczona pomiędzy dwiema zielonymi symetrycznymi gałązkami. Motyw ten, przywodzący na myśl ludowe zdobienia, nie wydaje się $\mathrm{w}$ żaden sposób związany z głównym tematem kompozycji - śmiercią przez powieszenie. Dolna, ażurowana część płaskorzeźby została podzielona na dwa obrazy pionową belką mogącą stanowić część szubienicy. Po jej lewej stronie artysta umieścił dwóch wisielców, zaś po prawej zobrazował scenę wieszania. Charakterystyczna jest sylwetka mężczyzny wykonującego wyrok - ma on na sobie długą czarną sukmanę $\mathrm{z}$ czerwonymi wykończeniami oraz czerwone nakrycie głowy w kształcie czepca i w zestawieniu z wisielcami ubranymi $\mathrm{w}$ nieprzykuwające uwagi stroje codzienne wygląda bardzo charakterystycznie. Co więcej, mężczyzna ten ma gęstą brodę. Być może jego postać ma uosabiać Żyda, wiadomo bowiem, że władze niemieckie niejednokrotnie wykorzystywały osoby tej narodowości do wykonywania wyroku powieszenia na Polakach, co miało na celu dodatkowe skonfliktowanie obu grup narodowościowych ${ }^{15}$, jednak teza ta nie wydaje się możliwa do udowodnienia z powodu niejednoznaczności omawianej postaci. Ludowe zdo-

14 Zob. J. Struk, Holokaust w fotografiach. Interpretacje dowodów, Warszawa 2007.

15 Przypadki takie pojawiają się w wielu wspomnieniach i w dokumentacji fotograficznej, mówił o nich też A. Chwalba w dyskusji: Debata klubu ekspertów „Rzeczpospolitej” i Ośrodka Karta wokót książek wydanych w serii „Żydzi polscy”, za: <http://www.rp.pl/ artykul/685015.html?print=tak\&p=0> [13.01.2015]. 
bienie z górnej części płaskorzeźby wydaje się w tym kontekście wręcz przypadkowe, wykonane w celu zapełnienia pustej przestrzeni oraz podkreślenia ludowego charakteru pracy ${ }^{16}$.

Czwarta część cyklu Oświęcim zatytułowana Gazowanie przedstawia grupę nagich kobiet $\mathrm{z}$ dziećmi stłoczonych w komorze gazowej. Przedstawione postaci są wyraźnie przestraszone, o czym świadczą ich skulone sylwetki, załamane ręce, przyciskanie do siebie dzieci. To chwila tuż przed śmiercią w komorze gazowej, a zatem plastyczna realizacja największego $\mathrm{z}$ holokaustowych tabu, przedstawienie niewyrażalnego, nadanie kształtu wyobrażeniu o wydarzeniu pozbawionym świadków. Fakt, iż wśród osób gazowanych znajdują się jedynie kobiety i dzieci służy zapewne wzmocnieniu siły wyrazu makabrycznej sceny. Ściany krematorium mają białą barwę, co dodatkowo wzmacnia związane z kształtem kompozycji skojarzenie z macewą. Półokrągłą część płaskorzeźby artysta ozdobił dodatkowo brązową sylwetką stojącego lwa, którą kojarzyć należy zapewne ze znanym rzeźbiarzowi z kirkutów żydowskim symbolem Lwa Judy. Tytuł Gazowanie nosi również ostatnia część cyklu. Podobnie jak poprzednia płaskorzeźba przedstawia ona komorę gazową, tym razem jednak proces gazowania ukazał artysta z zewnątrz budynku - jako niewidoczny dla obserwatora proces, poprzez który żywy człowiek przekształcany jest w odpadki - zwłoki. Centralny punkt kompozycji stanowi fragment ceglanego muru, który dzieli pracę na dwie zasadnicze części: po jego prawej stronie widać nagą kobietę wchodzącą do wnętrza, zaś z lewej strony ze ściany wypadają trupo białe zwłoki. Na lewo od nich znajdują się więzień oraz kontrolujący jego pracę żołnierz w niemieckim mundurze ${ }^{17}$. Trudno orzec, czy górujący nad zwłokami więzień w pasiaku wyciąga ciało z komory gazowej, czy może wkłada je do pieca krematoryjnego, jednak jeśli uznać, że płaskorzeźba zgodnie z tytułem przedstawia gazowanie ofiar, najważniejszy i najbardziej złowrogi moment procesu scena uśmiercania odgrywa się poza oczyma widza, za symbolicznym murem fabryki śmierci. W półokrągłej części płaskorzeźby artysta umieścił zdobienie w formie dwóch skrzyżowanych strzelb przywodzących na myśl estetykę myśliwską.

16 Zdobienie takie może być realizacją wskazań formułowanych przez komunistów $\mathrm{w}$ ramach wprowadzania do sztuki socrealistycznej tzw. formy narodowej, co w praktyce polegać miało na stosowaniu przez artystów motywów ludowych i folklorystycznych. J. Studzińska, Socrealizm..., s. 45-46.

17 To jedyny żołnierz przedstawiony w cyklu Skrętowicza, o którym jednoznacznie powiedzieć można, że należy do sił zbrojnych III Rzeszy, ma bowiem odpowiednie umundurowanie. 


\section{Franciszek Skocz, kompozycja Oświęcim}

Kompozycja Oświęcim składa się z szesnastu stojących na niewielkich podstawkach figurek wyrzeźbionych w polichromowanym drewnie: trzech esesmanów i czternastu więźniów (na jedną z figurek składają się dwie postaci). Powstały one w 1978 roku jako dzieło Franciszka Skocza, rzeźbiarza ludowego z Pyrzyc. Wysokość figurek przedstawiających postaci stojące waha się od $21 \mathrm{~cm}$ (Więzień numer $321 \mathrm{z}$ klocem) do 41,5 cm (jeden z esesmanów). Figurki przedstawiające załogę SS (41,5, 35 i 31,5 $\mathrm{cm})$ są wyraźnie wyższe od figurek więźniów $\left(21^{18}\right.$ do $\left.27,5 \mathrm{~cm}\right)$. Postaci więźniów zostały wyposażone w przedmioty pozwalające rozpoznać pracę, jaką wykonywali oni w obozie lub rodzaj kary, jakiej podlegali. Mamy tu do czynienia ze swoistymi obozowymi typami ludzkimi. Rzeźbiarz chciał najprawdopodobniej przedstawić przekrój życia obozowego. Każdy z esesmanów został wyposażony w pistolet, a jeden (przedstawiony na zdjęciu) dodatkowo w pejcz. Dwaj więźniowie pełniący funkcję kapo (rozpoznajemy ich po podpisie na naszywkach na pasiakach figurek) posiadają narzędzia służące do bicia: pejcz lub kij. Siedem kolejnych figurek przedstawia więźniów przy pracy, którą najczęściej jest przenoszenie cegieł lub belek. Tylko jedna figurka (Więzień 201) przedstawia zwykłego, pozbawionego obozowych funkcji więźnia, który bezczynnie stoi. Jego cechą charakterystyczną jest jedynie smutny wyraz twarzy, można więc domniemywać, że za jego pomocą artysta chciał przekazać atmosferę emocjonalną obozu. Trzy dotychczas nie wymienione rzeźby przedstawiają kary, jakim podlegali więźniowie: jeden z nich stoi na baczność zakrwawiony, inny przyjmuje chłostę, a ostatni wisi na szubienicy. Jak pisze Stefania Krzysztofowicz, „rzeźba ludowa o tematyce kultowej z XIX i początku XX wieku wyrażała głównie atmosferę cierpienia, męki”19. Tradycja przedstawiania scen pasyjnych skłaniała prawdopodobnie artystów ludowych do nieunikania scen kaźni obozowej oraz ich plastycznego, dosłownego obrazowania. Figurki zostały wykonane $\mathrm{z}$ dużą dbałością o detale, zwłaszcza numery i oznaczenia obozowe oraz symbolikę przynależną mundurom SS. Drewniane postaci zostały pomalowane farbą olejną, farbą wodoczułą i lakierem. Niektóre elementy rzeźb dla zachowania większej precyzji i realizmu zostały wykonane $\mathrm{z}$ gotowych znalezionych elementów, jak na przykład (wycięte najprawdopodobniej z obrazków opublikowanych w prasie i doklejone) oczy i usta esesmana czy Orzeł Rzeszy - godło III Rzeszy na jednej z czapek SS. Pisząc o sztuce ludowej w Polsce, Stefania Krzysztofowicz podkreśla rzadkość stosowania tego

${ }^{18}$ Figurka Więzień $w$ czasie chłosty ma wysokość $12,5 \mathrm{~cm}$.

19 S. Krzysztofowicz, O sztuce ludowej w Polsce, s. 39. 
typu zabiegów oraz fakt, że miały one uczynić figurki bardziej autentycznymi i żywymi ${ }^{20}$.

Większość figurek przedstawiających więźniów obozu ma na pasiaku czerwone trójkąty - oznaczenia więźniów „politycznych”, których przeważającą część stanowili w KL Auschwitz Polacy. Część figurek została oznaczona podobnym trójkątem w kolorze niebieskim. Trudno rozszyfrować jego znaczenie, ponieważ tego typu symbol nie był stosowany w Auschwitz na oznaczenie dużej grupy więźniów (w trochę innej tonacji oznaczać miał „emigrantów”). Jako że barwę tę Skocz przypisuje więźniom pełniącym funkcję kapo (ich funkcję pełnili głównie „kryminalni”), a także ze względu na pewne podobieństwo barw niebieskiej i zielonej można domniemywać, że Staszak oznaczył w ten sposób więźniów kryminalnych, którym w Auschwitz przypadał symbol zielonego trójkąta. Więźniami tej kategorii byli w tym obozie głównie Niemcy. Wśród czternastu figurek więźniów pojawia się tylko jeden Żyd. Został on oznaczony na piersi i plecach gwiazdą Dawida na białym tle obramowaną żółtym okręgiem oraz czerwoną opaską z napisem „Jude”. Tego typu oznaczenia nie funkcjonowały w KL Auschwitz. Żyda wyróżnia poza tym pewna cecha fizyczna, nad którą wypada się w tym kontekście dłużej zastanowić. Badając obraz Żyda w polskiej kulturze, Alina Cała zauważyła, że przed drugą wojną światową na wsi postać Żyda rozpoznawano przede wszystkim po sposobie ubierania. Według badaczki nie przypisywano wtedy Żydom specyficznych cech rasowych przejawiających się w wyglądzie fizycznym. Dopiero rozpropagowanie przez Niemców fizjonomiki i stosowanie przez nich stereotypu wyglądu semickiego, który miał umożliwiać rozpoznanie Żydów, spowodowało, że polska wieś zaczęła przedstawiać Żydów jako ludzi o wyjątkowo wydatnych nosach ${ }^{21}$. Dzieje się tak również w wypadku Skocza, który przedstawia Żyda w pasiaku, nie ma więc mowy o zaznaczeniu jego tożsamości za pomocą stroju obrzędowego. Jako więzień obozu Żyd jest również pozbawiony zarostu. Badając tę figurkę, nie sposób nie zauważyć, że rzeźbiarzowi szczególnie zależało $\mathrm{w}$ tym przypadku na wyraźnym zaznaczeniu jego tożsamości - symbole związane z (błędnymi, przywodzącymi na myśl raczej te funkcjonujące w gettach) oznaczeniami kategorii więźniów są tu szczególnie duże i wyraźne. Wyodrębnieniu tej grupy więźniów służyć ma zapewne również wyposażenie figurki w przedstawiony na zdjęciu wydatny nos.

Zaskakującym elementem cyklu Oświęcim jest figurka przedstawiająca dwóch czarnoskórych więźniów niosących drewno na specjalnych

20 Tamże, s. 45.

21 A. Cała, Żyd - wróg odwieczny? Antysemityzm w Polsce $i$ jego źródła, Warszawa 2012. 
noszach. Nie może tu być mowy o błędnym zinterpretowaniu rzeźby, gdyż artysta nadał figurce tytuł Więźniowie murzyńscy oraz obdarzył postaci wydatnymi wargami. Powód dołączenia czarnoskórych do zbiorowości więźniarskiej nie jest jasny, można jednak domyślać się, że artysta popełnił błąd na skutek ciągu skojarzeniowego. Skocz zdawał sobie sprawę z rasistowskiego charakteru hitlerowskich obozów i dokonał kontaminacji tej wiedzy z przeświadczeniem, że rasizmem nazywamy dyskryminację osób czarnoskórych. Sądzę, że hipoteza taka najlepiej tłumaczy zaliczenie czarnoskórych w poczet więźniów KL Auschwitz. Rzeczą zastanawiającą wydaje się zaburzenie proporcji ilościowych wśród grup przedstawionych przez Skocza jako ofiary Auschwitz. Najliczniejsza grupa - Żydzi - jest reprezentowana zaledwie przez jedną (na dodatek uśmiechniętą, pogodną) figurkę, większość więźniów (także całość spośród tych, którzy zostali przedstawieni jako cierpiący, karani) stanowią Polacy, zaś czarnoskórzy, których w historycznym KL Auschwitz nie było, są reprezentowani przez dwie postaci. Nie sposób jednoznacznie stwierdzić, co przyczyniło się do tak drastycznego zachwiania proporcji (liczba Polaków może być zawyżona ze względu na tendencje do martyrologizowania losu narodu, ale jak wytłumaczyć stosunek Żydów do czarnoskórych?). Biorąc pod uwagę czas powstania pracy, można domniemywać, że wpłynęła na to antysemicka propaganda okresu PRL oraz polityka zaniżania liczby żydowskich ofiar KL Auschwitz. Wytwory sztuki przedstawiającej obóz w formie scenek, na które składają się figurki o ludzkich kształtach, muszą być z założenia kontrowersyjne. Ernst van Alphen pisze: „w kontekście edukacji i pamięci Holokaustu nienaruszalny aksjomat mówi, że gatunki i dyskursy historyczne, takie jak dokument, wspomnienie, świadectwo czy pomnik są znacznie bardziej efektywne i znacznie bardziej odpowiedzialne moralnie niż dyskursy oparte na wyobraźni”22. Jak wspomniałam, figurki składające się na cykl Skocza Oświęcim przedstawiają typy ludzkie i prawdopodobnie mają stanowić swoistą panoramę życia obozowego. Są oparte na wyobraźni twórcy, co sprawia, że cykl Skocza okazuje się bardzo problematyczny - gdyby koncept tego typu zrealizował artysta spoza kręgu kultury ludowej, najprawdopodobniej można by zarzucić mu uzurpację, jakoby poprzez działania estetyczne sprzeniewierzał się wyzwaniom etycznym, jakie stawia przed nim problem Zagłady. Cechą sztuki ludowej jest jednak fakt, iż nie może ona być interpretowana w tych samych kategoriach, w jakich rozważana bywa sztuka wysoka. Dbałość o detal cechująca poszczególne figurki oraz chęć przedstawienia w miarę pełnego

22 E. van Alphen, Zabawa w Holokaust, przeł. K. Bojarska, „Literatura na Świecie” 2004, nr 1-2. 
Władysław Chajec

(Muzeum Etnograficzne im. Seweryna Udzieli w Krakowie)

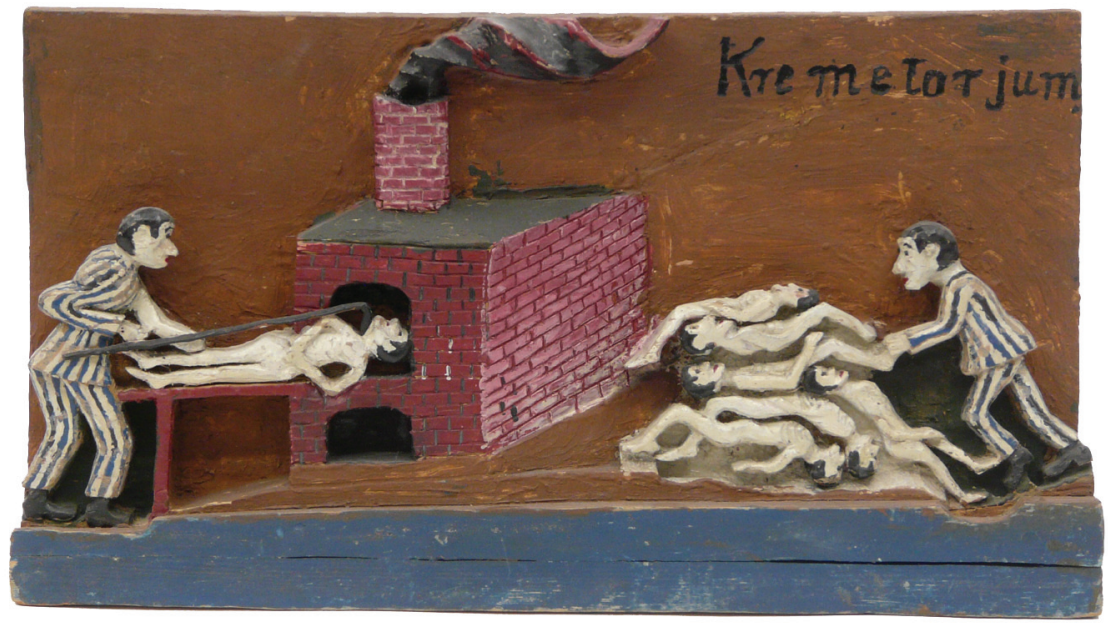

Krematorjum 


\section{Zygmunt Skrętowicz (rzeźby z kolekcji \\ Państwowego Muzeum Etnograficznego w Warszawie)}

Nowy transport. Oświęcim I

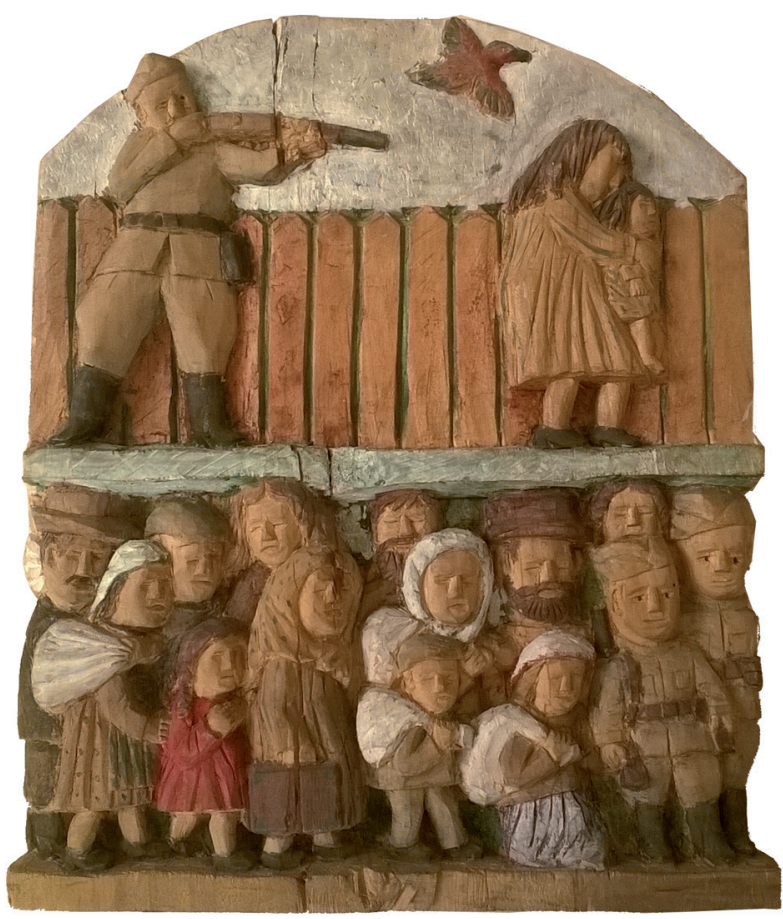

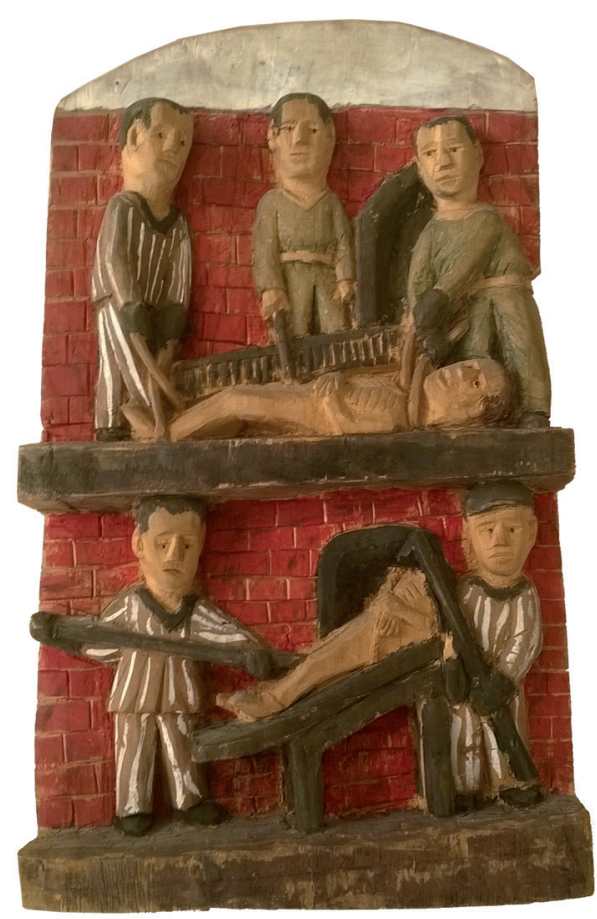

Krematorium. Oświęcim II

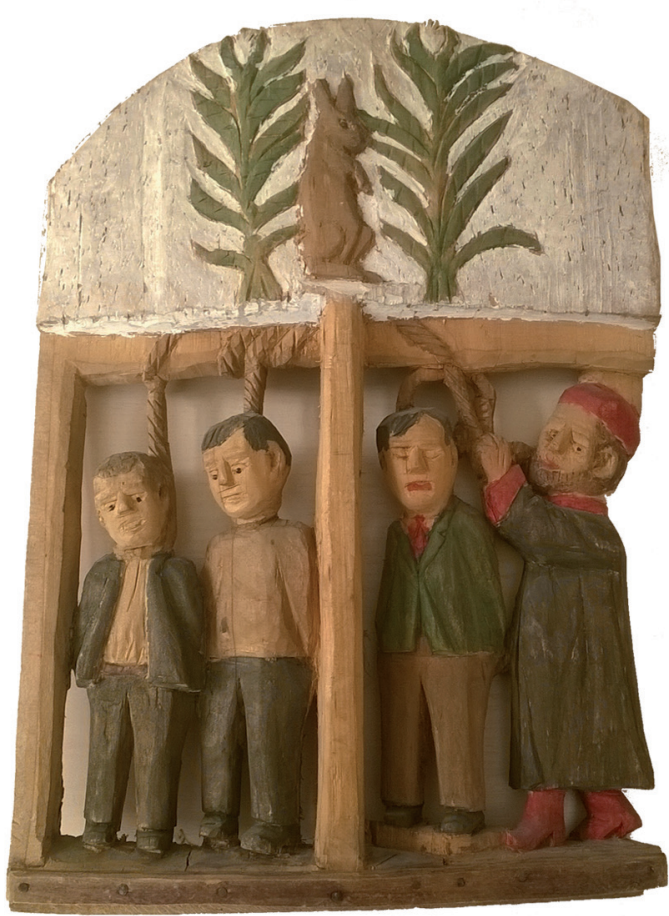

Wieszanie. Oświęcim III 


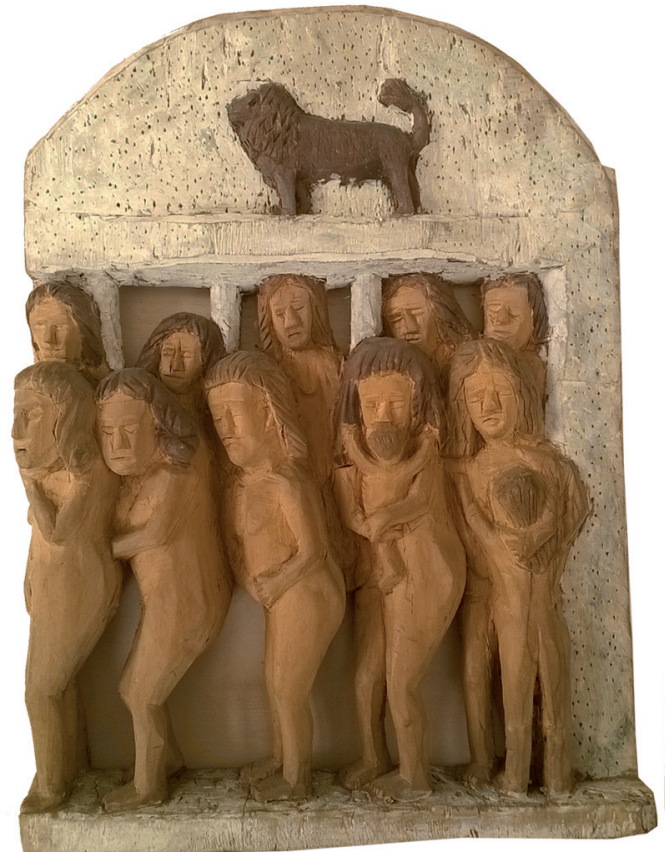

Gazowanie. Oświęcim IV

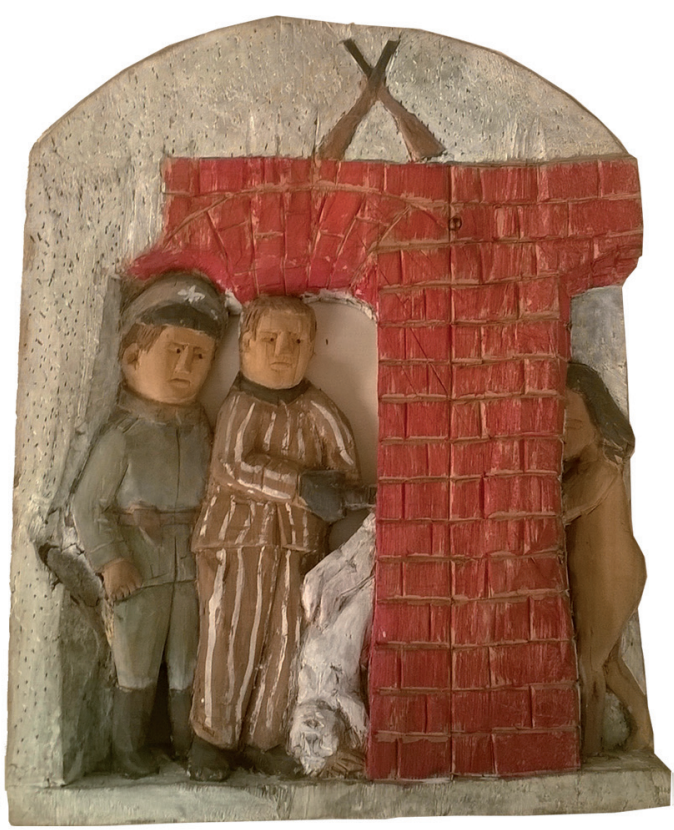

Gazowanie. Oświęcim V 


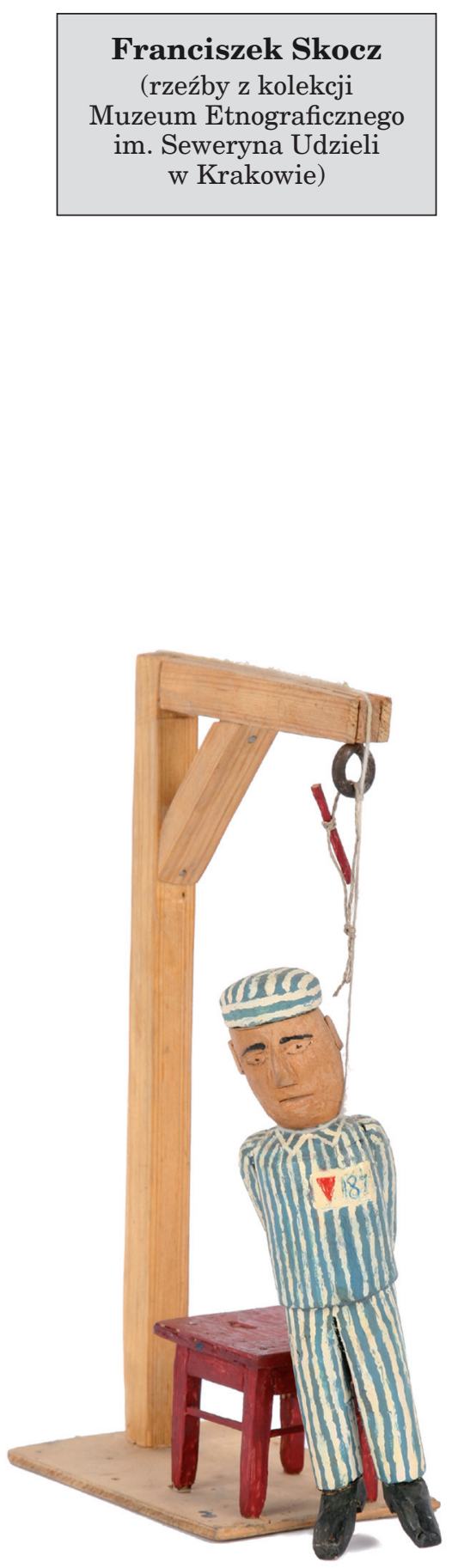

Więzień na szubienicy

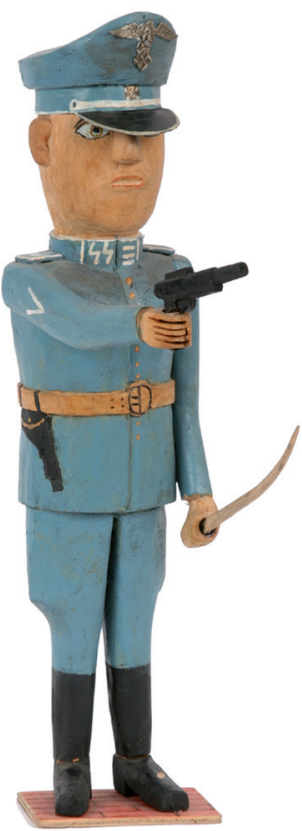

SS-mann

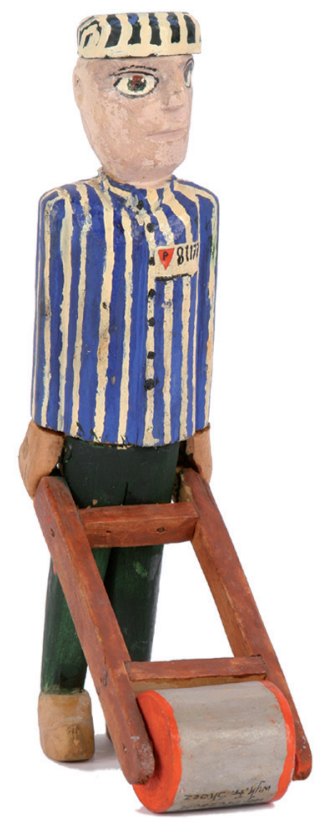

Więzień nr 81177

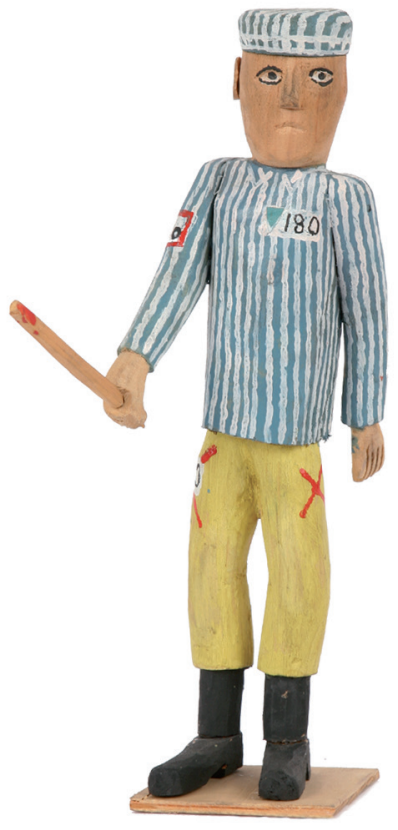

Kapo nr 180 z pałką

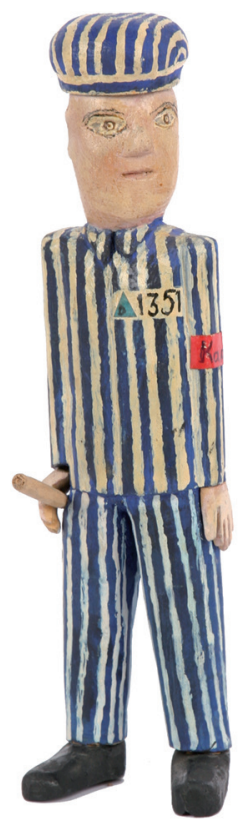

Więzień nr 1351 


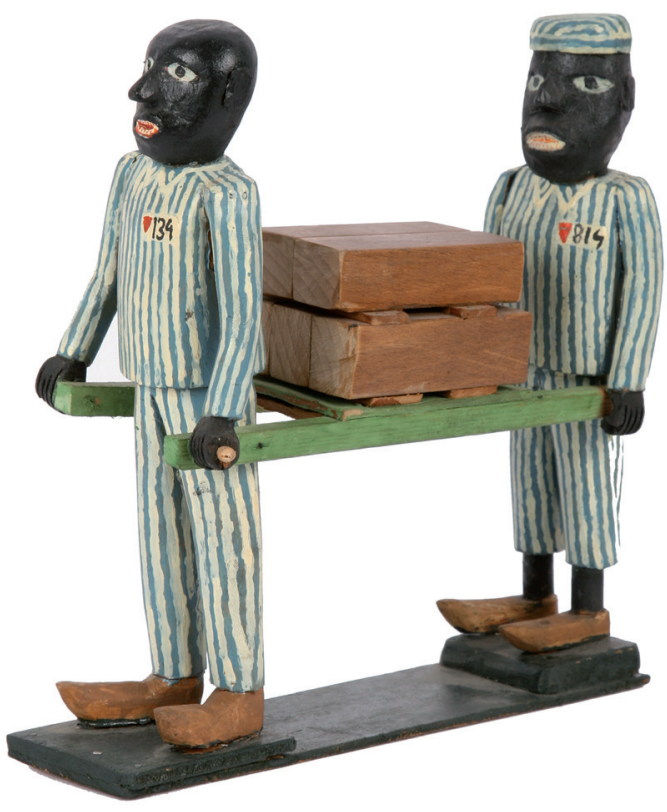

Więźniowie murzyńscy

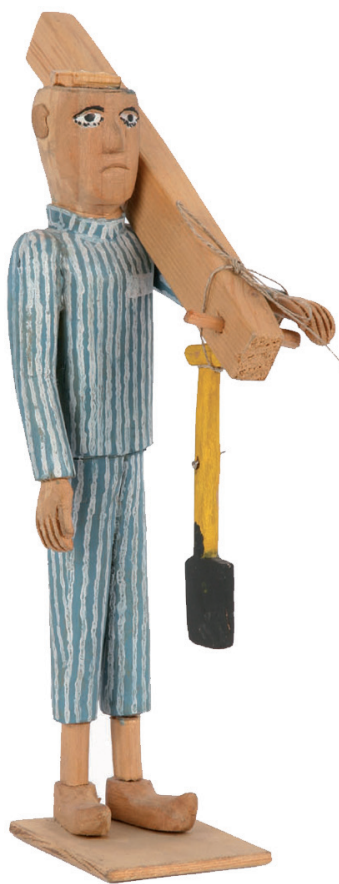

Więzień z belką na ramieniu

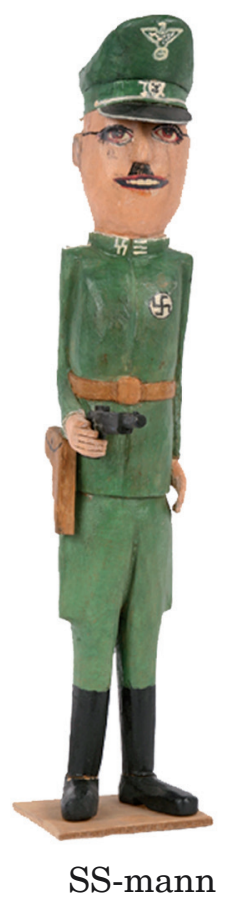

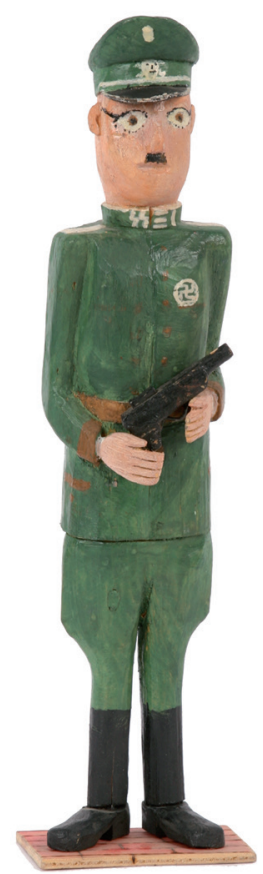

SS-mann

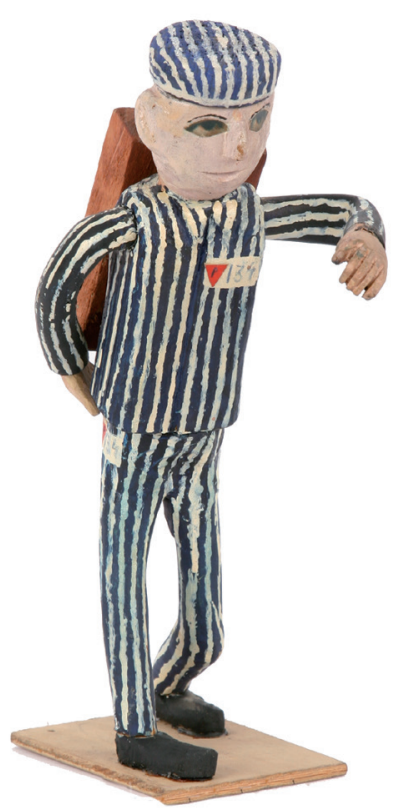

Więzień nr 134 


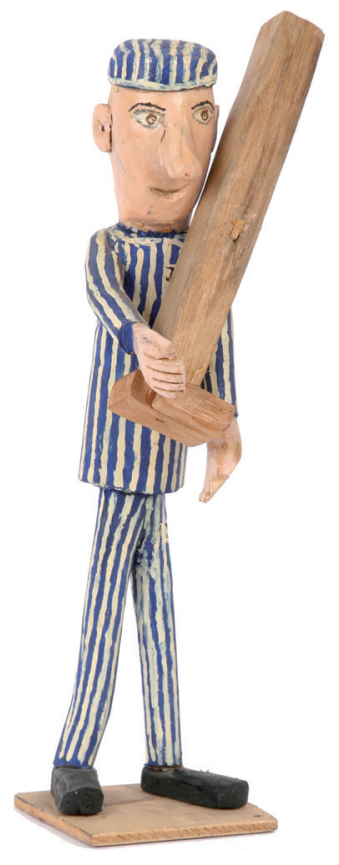

Więzień-Żyd z kłodą

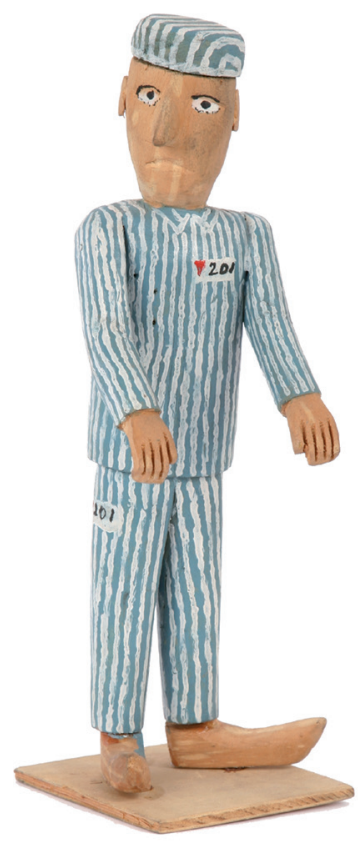

Więzień nr 201

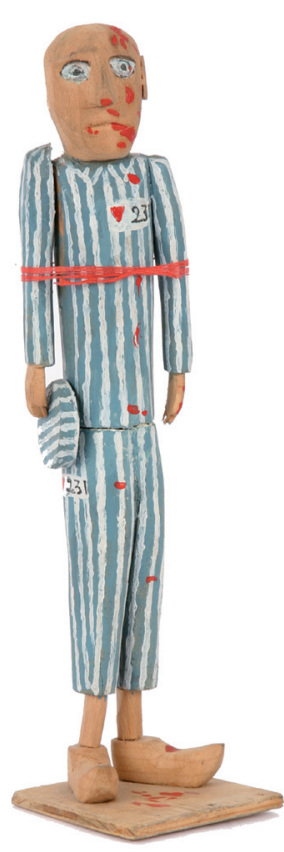

Więzień nr 231

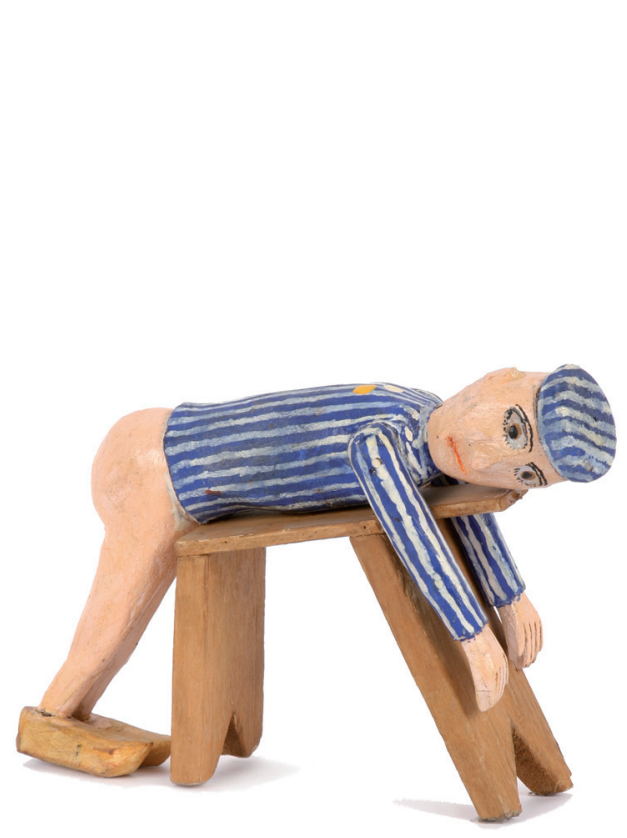

Więzień w czasie chłosty

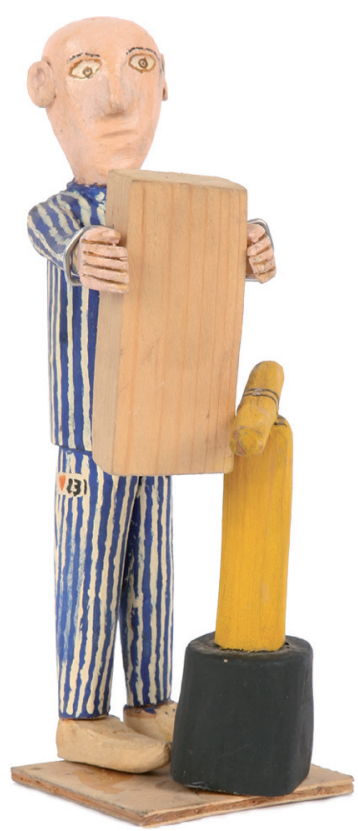

Więzień nr 321 z klocem

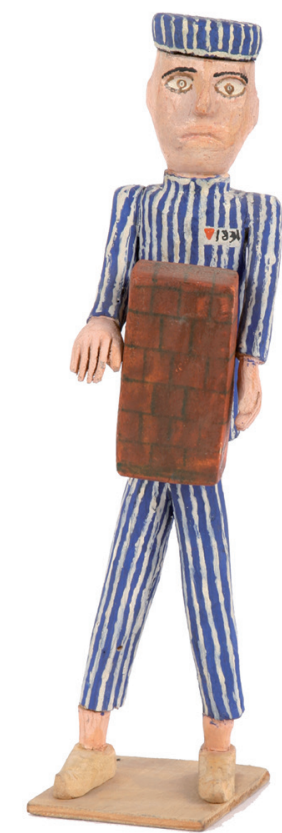

Więzień nr 1831 


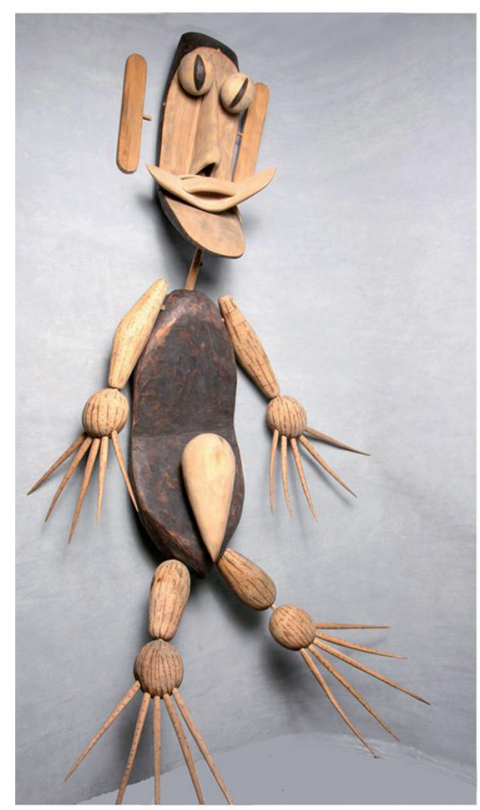

Sęp
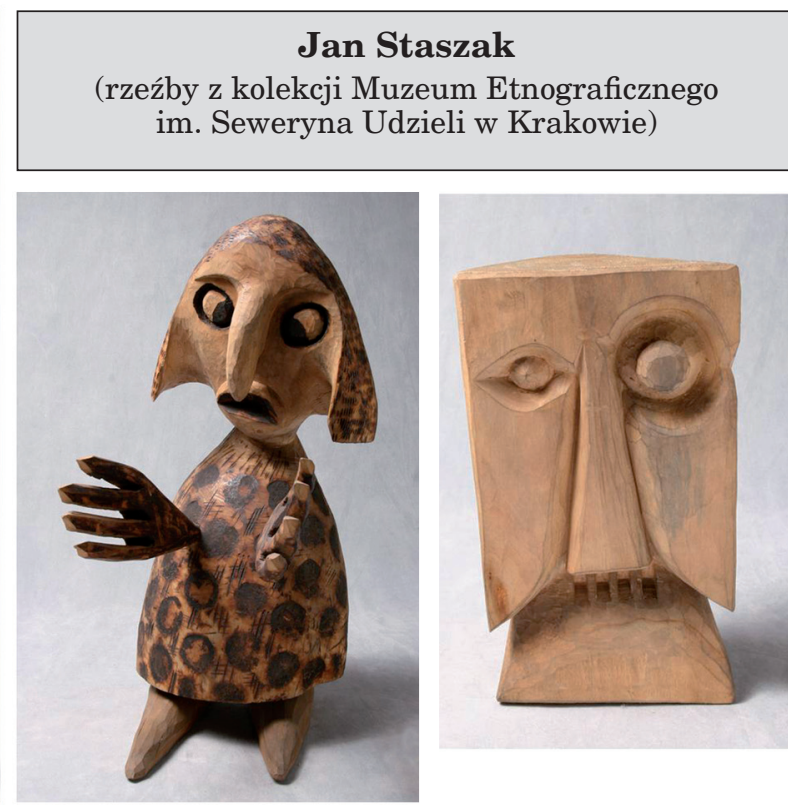

Czarownica

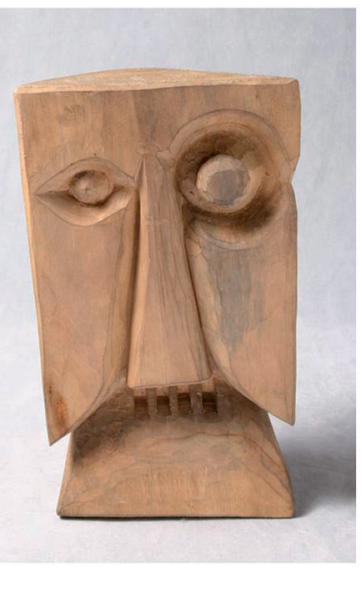

Złość

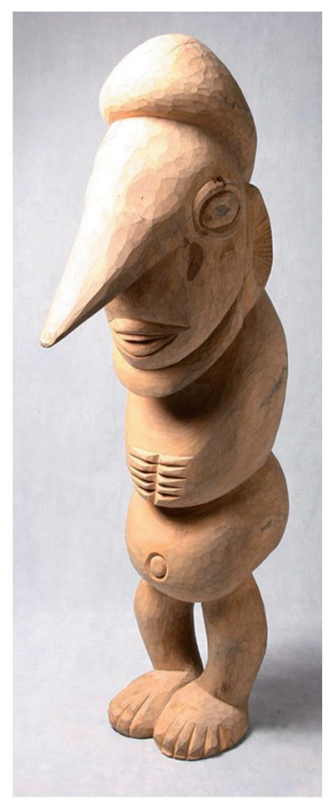

Człowiek

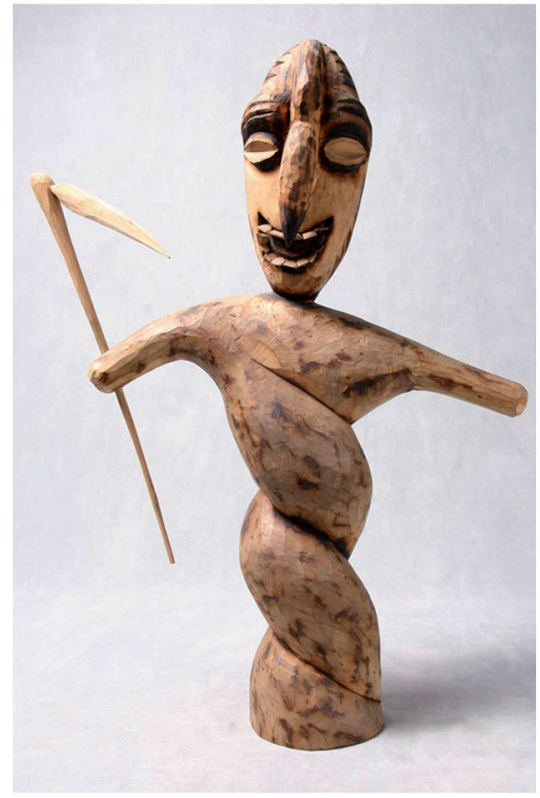

Kostucha

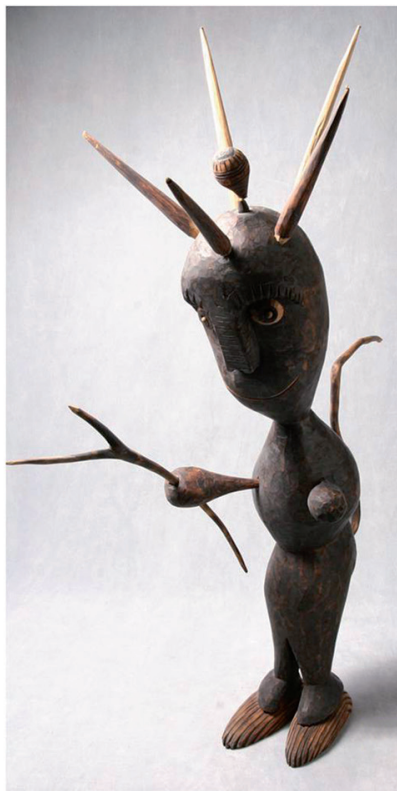

Antychryst 


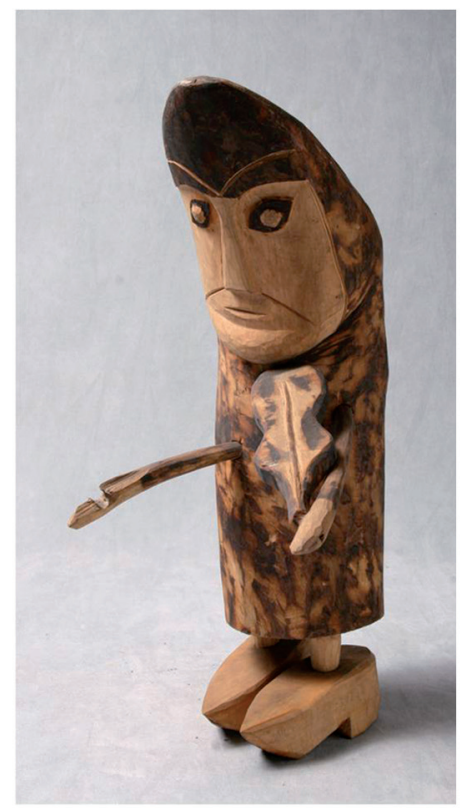

Skrzypek

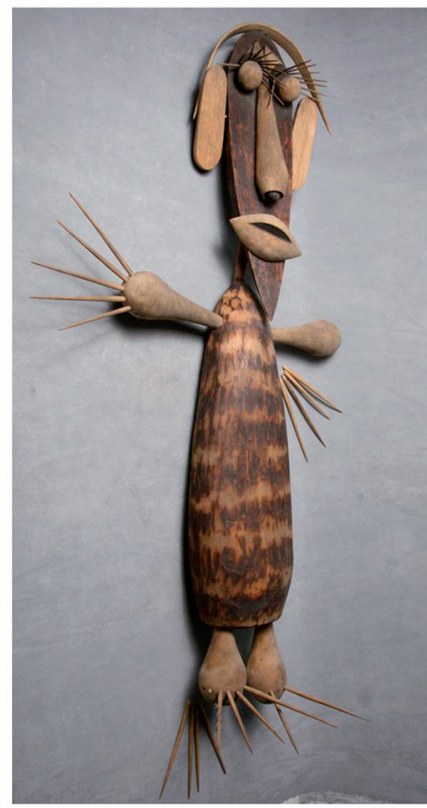

Sępica 
spektrum obozowych przeżyć wskazuje na edukacyjną rolę, jaką Skocz mógł przypisywać swojemu cyklowi. Jeśli weźmiemy pod uwagę sakralną historię rzeźby ludowej i jej w dużej mierze religijny rodowód, będziemy mogli zauważyć, że w kulturze wsi głęboko zakorzeniona jest tradycja przekazywania najbardziej skomplikowanych prawd i nakazów moralnych za pomocą sztuki przedstawiającej - to za jej pomocą Kościół katolicki docierał do swoich niepiśmiennych wiernych. Rola sztuki figuratywnej, ułatwiającej wiernym drogę do odczuwania sacrum, wskazuje na fakt, iż w twórczości ludowej oddawanie zjawisk nieprzedstawialnych za pomocą realistycznych figur nie jest świadectwem uzurpacji estetycznej, ale ma cel głęboko etyczny, edukacyjny.

\section{Rzeźbiarstwo Jana Staszaka}

Jan Staszak nawiązuje w swojej twórczości do Holokaustu w sposób odmienny niż autorzy wcześniej omówionych rzeźb. Zazwyczaj nie przedstawia zdarzeń czy postaci związanych z obozem, a przynajmniej nie robi tego w sposób realistyczny. Staszak zajmuje się raczej ludowymi podaniami oraz motywami obyczajowymi. Mimo to każda z jego dojrzałych prac w sposób bezpośredni pozostaje związana z obozem KL Auschwitz-Birkenau. Po zawarciu związku małżeńskiego artysta osiedlił się we wsi Harmęże leżącej w powiecie oświęcimskim, niecałe dwa kilometry od granic byłego obozu Auschwitz-Birkenau. Miejsce to znane jest z opowiadania Tadeusza Borowskiego Dzień na Harmenzach:

Cień kasztanów jest zielony i miękki. Kołysze się lekko po ziemi jeszcze wilgotnej, bo świeżo skopanej, i wznosi się nad głową seledynową kopułą pachnącą poranną rosą. Drzewa tworzą wzdłuż drogi wysoki szpaler, a czuby ich rozpływają się w kolorycie nieba. Odurzająca woń bagna ciągnie od stawów. Trawa zielona jak plusz srebrzy się jeszcze rosą, ale ziemia już paruje w słońcu ${ }^{23}$.

Jak dowiadujemy się z opowiadania, do wspomnianych w powyższym fragmencie stawów wrzucono popiół ze spalonych zwłok ofiar obozu Auschwitz. Jego więźniowie pracowali we wsi Harmęże głównie przy pracach hodowlanych, a pod koniec 1941 roku powstał tu jeden z pierwszych podobozów KL Auschwitz o nazwie Harmense. Jan Staszak osiedlił się zatem we wsi naznaczonej bolesną historią, w miejscu, którego przyroda zdaje się pamiętać los więźniów, a także być z nim w pewnym sensie bezpośrednio związana, gdyż, jakkolwiek trywialnie by to zabrzmiało, prochy

23 T. Borowski, Wybór opowiadań, Warszawa 1998, s. 118. 
tysięcy ofiar nie mogły pozostać bez wpływu na lokalny ekosystem. Fakt ten miał zasadnicze znaczenie dla rozwoju twórczości artystycznej rzeźbiarza, który zaczął wykonywać swe figurki tylko z drewna drzew rosnących na tej przestrzeni, tuż obok obozu Auschwitz-Birkenau. Wydaje się, że Staszak przypisywał tym roślinom szczególne znaczenie - fakt, że rosły w bezpośrednim sąsiedztwie Zagłady predestynował je do roli swoistych świadków.

Dla rzeźbiarzy ludowych materiał, na jakim pracują, ma szczególne znaczenie. Często wyznacza nie tylko formę, ale również tematykę pracy. Stefania Krzysztofowicz podkreśla, że najważniejsze elementy rzeźby ludowej, za jakie uznaje się jej bryłę, ornament i ekspresję „w zdecydowany sposób łączą się zawsze z materiałem rzeźbiarskim, czyli surowcem, pozostając w bezpośredniej zależności od niego"24. Na temat, jakim zajmuje się rzeźbiarz ludowy, wpływa zatem kształt kawałka drewna, w którym rzeźbi, jego faktura, czy układ sęków. Jeśli Jan Staszak uważał drzewa stojące na pograniczu obozu za świadków zdarzeń, można uznać, że traktował swoją pracę jak wydobywanie (na podstawie kształtu drewna) i opracowywanie śladu zdarzeń, swoistej narracji bólu, w sąsiedztwie którego rosły. Początkowo zajmował się tematyką ściśle związaną z drugą wojną światową. Powstały wtedy takie prace, jak Oświęcimski Chrystus Krematoryjny, Pierwsze spojrzenie na obóz, Gaz, Krzyk czy Więźniarka ${ }^{25}$, których cierpienie oddane za pomocą ekspresyjnej mimiki oraz niemal abstrakcyjnego wyginania członków zasugerowanych artyście przez kształt materiału rzeźbiarskiego. Powróciwszy do tworzenia rzeźb związanych z tematami ludowymi oraz postaci z życia codziennego Staszak nadal używał drewna z pogranicza Auschwitz, przez co jego twórczość pozostawała w znaczący sposób naznaczona cierpieniem z czasów drugiej wojny światowej. Wyjątkową cechą rzeźbiarstwa Staszaka jest łączenie w jednej figurce kilku kawałków drewna, co można uznać za przekroczenie zasad rządzących rzeźbą ludową ${ }^{26}$, artysta stosuje też w swojej działalności plastycznej opalanie drewna - jego zwęglenie kojarzone bywa $\mathrm{w}$ tej twórczości między innymi z żarem krematorium ${ }^{27}$.

Jednym z ulubionych tematów Staszaka są postaci przeklętych, pół ludzi, pół zwierząt lub przedmiotów. Jest to o tyle specyficzne, że według

${ }^{24}$ S. Krzysztofowicz, O sztuce ludowej w Polsce, s. 41.

${ }_{25}$ Zob. J. Kupiec, Auschwitz w rzeźbie ze zbiorów Państwowego Muzeum Auschwitz-Birkenau w Oświęcimiu, Oświęcim 2006, s. 107-111.

26 „Do rzadkości w rzeźbie ludowej należy łączenie kawałków drewna. «Regulaminowo», rzec można, ryto w jednym kawałku drewna". S. Krzysztofowicz, O sztuce ludowej $w$ Polsce, s. 44.

27 J. Kupiec, Auschwitz w rzeźbie..., s. 107. 
badaczy twórczości ludowej współcześnie temat ten zdaje się zanikać28. Trudno powiedzieć, czy wybór takiej tematyki ma jakikolwiek związek z pochodzeniem drewna wykorzystywanego do produkcji figurek, jednak trudno zaprzeczyć, iż decyzja o jego dalszym stosowaniu poprzez całe życie twórcze świadczy o symbolicznej akceptacji faktu, iż sztuka po Zagładzie nie może od niej abstrahować, pozostaje nią naznaczona, powstaje w jej cieniu.

Częściowo ludzkie figury Staszaka cechuje bardzo przejmująca ekspresja - ich nieproporcjonalne ciała, wyolbrzymione kończyny, głowy, nosy przydają postaciom specyficzny wyraz ${ }^{29}$. Jak już wspomniałam, kształt figur jest bezpośrednio zdeterminowany przez cechy kawałków drewna, z jakich zostały wyrzeźbione, można zatem odnieść wrażenie, że ból, smutek i nieszczęście związane z obozem w jakiś sposób przenikały do analizowanych figur.

Analiza powyższych przykładów sztuki ludowej poświęconej obozom hitlerowskim wskazuje, iż do jej opisu potrzebny jest język odmienny od używanego do badania tekstów przynależnych do tak zwanej kultury wysokiej. W związku z brakiem takiego języka trudno o stabilne kryteria pozwalające na omówienie zaprezentowanych w tekście rzeźb. Jego wykształcenie prowadzić mogłoby do odkrycia sposobów mówienia o Zagładzie i innych cierpieniach związanych z drugą wojną światową i doświadczeniami granicznymi niedostępnych sztuce elitarnej, a przy tym niezwykle ciekawych poznawczo i etycznie. W wypadku rzeźby ludowej stworzenie dzieła całościowego, skończonego w swej pełni i sile podmiotu niwelującego inność i różnicę, a zatem podporządkowującego etykę estetyce wydaje się mało prawdopodobne, gdyż ludowość ze swej natury zakłada różnorodność i poddanie się materii stanowiące zaprzeczenie silnego ,ja" twórcy ${ }^{30}$. Nie ulega wątpliwości, iż rzeźbiarze ludowi, konstruując swoje prace, dążyli przede wszystkim do podkreślenia tragizmu ukazywanych scen i postaci, grozy obozowego piekła, co ciekawe unikali oni przy tym patosu na rzecz dosłowności. Prymat funkcji ideowej i dydaktycznej nad etyczną wywoływał u twórców ludowych dążenie do zwięk-

28 „We współczesnej rzeźbie ludowej stosunkowo skromne miejsce zajmuje tematyka baśniowa, wynikająca z ludowej wyobraźni, fantastycznych interpretacji ludowych opowieści o Borucie, diabłach i innych bohaterach regionalnych legend". S. Krzysztofowicz, O sztuce ludowej $w$ Polsce, s. 40.

29 „Za szczególną wartość rzeźby ludowej uznać należy jej wyraz - ekspresję [...] Wynika ona $\mathrm{z}$ chęci pokazania bólu, smutku, nieszczęść, które mają być czytelne i zgodne z myślą artystyczną, a wyrażają je między innymi bardzo silne niekiedy deformacje rzeźbionych figur: wyolbrzymione głowy, ręce, oczy". Tamże, s. 43.

${ }^{30}$ Por. A. Ubertowska, Świadectwo - trauma - głos, Kraków 2007. 
szenia wymowności i czytelności prac ${ }^{31}$. Powstawały one na podstawie zdjęć przedstawiających szczególnie brutalne sceny sfotografowane po wyzwoleniu obozów lub usiłowały ukazać proces mordowania ludzi w niemieckich fabrykach Zagłady poprzez jego artystyczne odtworzenie. Gesty takie, krytykowane na gruncie akademickim, wykonywane przez twórców ludowych świadczą o istnieniu ludzkiej potrzeby wyobrażenia sobie Holokaustu i pozwalają ponownie przemyśleć Adornowski zakaz przedstawiania oraz zagrożenia związane z estetyzacją bólu. Prace twórców ludowych, zepchnięte na margines dyskursu pamięciowego świadczą o odrzuconej przez kulturę wysoką strategii obrazowania.

\section{BIBLIOGRAFIA}

Alphen E. van, Zabawa $w$ Holokaust, przeł. K. Bojarska, „Literatura na Świecie” 2004, $\mathrm{nr} 1-2$.

Borowski T., Wybór opowiadań, Warszawa 1998.

Cała A., Żyd - wróg odwieczny? Antysemityzm w Polsce i jego źródła, Warszawa 2012.

Cwynar L., Ku ludowości, „Łabuź” 2002, nr 43, za: <http://labuz.art.pl/archiwlabuz/ 043labuz.html> [15.09.2013].

Czerepińska J., Czerepiński A., Władystaw Chajec, rzeźbiarz ludowy z Kamienicy Górnej, powiat Jasto, „Polska Sztuka Ludowa” 1961, z. 4, s. 233-242, 254.

Fryś-Pietraszkowa E., Kunczyńska-Iracka A., Pokropek M., Sztuka ludowa w Polsce, Warszawa 1988.

Grabowski J., O sztuce ludowej w Europie, Warszawa 1978.

Grabowski J., Sztuka ludowa, Warszawa 1977.

Jedlińska E., Sztuka po Holocauście, Łódź 2001.

Krzysztofowicz S., O sztuce ludowej w Polsce, Warszawa 1972.

Kupiec J., Auschwitz w rzeźbie ze zbiorów Państwowego Muzeum Auschwitz-Birkenau w Oświęcimiu, Oświęcim 2006.

Saltzman L., Awangarda i kicz raz jeszcze. O etyce reprezentacji, przeł. K. Bojarska, „Literatura na Świecie” 2004, nr 1-2.

Struk J., Holokaust w fotografiach. Interpretacje dowodów, Warszawa 2007.

Studzińska J., Socrealizm w malarstwie polskim, Warszawa 2014.

Ubertowska A., Świadectwo - trauma - głos. Literackie reprezentacje Holokaustu, Kraków 2007.

31 Trudno nie zauważyć, że te cechy sztuki ludowej poświęconej tematyce obozowej były też doskonałą realizacją rządzących realizmem socjalistycznym zaleceń dotyczących typowości, schematyczności, ideowości i zrozumiałości sztuki realistycznej. J. Studzińska, Socrealizm..., s. 251-253. Jako rzeźby zakupione przez muzea etnograficzne w latach sześćdziesiątych i siedemdziesiątych najprawdopodobniej z funduszy Ludowego Mecenatu Sztuki, analizowane prace musiały wpisywać się w linię ideologiczną państwa, a ponadto mogły też powstać z myślą o konkretnych zamówieniach i konkursach tematycznych. Tamże, s. 121-123, 480. 


\section{SPIS FOTOGRAFII}

Władysław Chajec, Krematorjum, nr 31395, Muzeum Etnograficzne w Krakowie.

Zygmunt Skrętowicz, Nowy transport. Oświęcim I, nr 26739, Państwowe Muzeum Etnograficzne w Warszawie.

Zygmunt Skrętowicz, Krematorium. Oświęcim II, nr 26735, Państwowe Muzeum Etnograficzne w Warszawie.

Zygmunt Skrętowicz, Wieszanie. Oświęcim III, nr 26736, Państwowe Muzeum Etnograficzne w Warszawie.

Zygmunt Skrętowicz, Gazowanie. Oświęcim IV, nr 26737, Państwowe Muzeum Etnograficzne w Warszawie.

Zygmunt Skrętowicz, Gazowanie. Oświęcim V, nr 26738, Państwowe Muzeum Etnograficzne w Warszawie.

Franciszek Skocz, SS-mann, nr 55467/1, Muzeum Etnograficzne w Krakowie.

Franciszek Skocz, SS-mann, nr 55467/2, Muzeum Etnograficzne w Krakowie.

Franciszek Skocz, Więzień nr 134, nr 55467/3, Muzeum Etnograficzne w Krakowie.

Franciszek Skocz, Więzień-Żyd z kłoda, nr 55467/4, Muzeum Etnograficzne w Krakowie.

Franciszek Skocz, Więzień nr 201, nr 55467/5, Muzeum Etnograficzne w Krakowie.

Franciszek Skocz, Więzień nr 231, nr 55467/6, Muzeum Etnograficzne w Krakowie.

Franciszek Skocz, Więzień $w$ czasie chłosty, nr 55467/7, Muzeum Etnograficzne w Krakowie.

Franciszek Skocz, Więzień nr 321 z klocem, nr 55467/8, Muzeum Etnograficzne w Krakowie.

Franciszek Skocz, Więzień nr 1831, nr 55467/9, Muzeum Etnograficzne w Krakowie.

Franciszek Skocz, Kapo nr 180 z patka, nr 55467/10, Muzeum Etnograficzne w Krakowie.

Franciszek Skocz, Więzień na szubienicy, nr 55467/11, Muzeum Etnograficzne w Krakowie.

Franciszek Skocz, Więzień z belka na ramieniu, nr 55467/12, Muzeum Etnograficzne w Krakowie.

Franciszek Skocz, Więzień nr 81177, nr 55467/13, Muzeum Etnograficzne w Krakowie.

Franciszek Skocz, Więzień nr 1351, nr 55467/14, Muzeum Etnograficzne w Krakowie.

Franciszek Skocz, Więźniowie murzyńscy, nr 55467/15, Muzeum Etnograficzne w Krakowie.

Franciszek Skocz, SS-mann, nr 55467/16, Muzeum Etnograficzne w Krakowie.

Jan Staszak, Sęp, nr 34297, Muzeum Etnograficzne w Krakowie.

Jan Staszak, Czarownica, nr 34301, Muzeum Etnograficzne w Krakowie.

Jan Staszak, Złość, nr 34309, Muzeum Etnograficzne w Krakowie.

Jan Staszak, Człowiek, nr 34313, Muzeum Etnograficzne w Krakowie.

Jan Staszak, Kostucha, nr 34315, Muzeum Etnograficzne w Krakowie.

Jan Staszak, Antychryst, nr 34316, Muzeum Etnograficzne w Krakowie.

Jan Staszak, Skrzypek, nr 34632, Muzeum Etnograficzne w Krakowie.

Jan Staszak, Sępica, nr 34635, Muzeum Etnograficzne w Krakowie. 